\title{
Decolonizing the African Studies Centre
}

Adam Branch, University of Cambridge

Forthcoming in Cambridge Journal of Anthropology, vol. 36, no. 2 (2018).

\begin{abstract}
The African Studies Centre has been a privileged institutional form in Britain for knowledge production on Africa since the end of colonialism. This article argues that the origin of these UK centres should be located in the colonial research institutes established in Africa, in particular the Rhodes-Livingstone Institute and the East African Institute of Social Research. Attention to the knowledge about Africa that was deemed authoritative by these institutes as well as to the institutions and structures underpinning that knowledge production can raise important questions about today's centres that need to be addressed as part of a decolonization agenda.
\end{abstract}

\section{Decolonizations of African Studies}

Colonial legacies are not hard to find in African Studies in the UK today, from the annual Lugard Lecture to the Royal African Society, from Rhodes' refusal to fall at Oxford to the Smuts Memorial Trust at Cambridge. The anti-colonial, Pan-African and transcontinental traditions of African Studies, with their focus on the African diaspora, race and Africa-centred knowledge, were not institutionalized within British universities to the extent they were in some African and North American universities (Zeleza 2007). Although many prominent African intellectuals critical of the Western tradition of scholarship on Africa - from Kwame Nkrumah to Jomo Kenyatta, Kofi Busia, Okot p'Bitek and Archie Mafeje - attended British universities, they largely did not remain within UK academia, instead returning to intellectual life in Africa (Ntarangwi et al. 2006). There was of course important Pan-African intellectual and political activity in the UK, but it has not appeared to have had much influence on disciplinary African Studies. While those on the inside of British African Studies may have been 'actively helping to give young Africans a subversive voice at the seat of empire' (Lonsdale 2005: 387), those Africans rarely, it seems, got an actual seat. Neither has the longstanding work of UK-based academics on the Black Atlantic, on Pan-Africanism, on the Caribbean or on race (Adi 1998; Gilroy 1993; Hall 2017) presented the kind of challenge to UK African Studies that arose in the US, where mainstream African Studies was under serious pressure by the late 1960s. There is 
awareness within the British African Studies establishment of a possible challenge following the US precedent (Bundy 2002): as historian Anthony Kirk-Greene (2000: 32) writes, 'AfroCaribbean and "British African" youth could one day be knocking at (hopefully not down) the doors of Britain's Africanist community'. These anxieties are perhaps not unfounded, given the extent to which African Studies in the UK can still appear largely a preserve of white scholars.

At Cambridge, like at other UK universities, there are today flourishing debates and movements around decolonizing the university and decolonizing the curriculum. These largely student-led efforts have led to the formation of working groups in different departments, to public events, seminars, activist meetings and alternative reading lists. Demands for decolonization resounded in the early 2018 academic staff strike and were the subject of teachouts (where this article was first presented). Decolonization was a demand of the student occupiers of Cambridge's Senate House, which even led to a declared commitment to decolonization from the Vice-Chancellor. The movements at Cambridge and in the UK are, of course, responding to and in conversation with the student and social movements in South Africa and the US around decolonization and Black Lives. This anti-racist, decolonial intellectual and social activism in former settler colonies and colonial metropoles represents an important opportunity for rethinking African Studies so that it is adequate to, in Akosua Adomako Ampofo's words, 'a time of Afro-revivalism as well as a heightened onslaught on Black bodies globally' (2016: 8).

Given African Studies' many histories and geographies, what decolonization means will also differ, entailing different temporalities, transformations and dilemmas. The long history of decolonizing knowledge about Africa - and about the world - within African universities should be a starting point for discussions (Mama 2007; Mamdani 2016; Zeleza 1997). But decolonizing African Studies within a former colonial metropole presents its own specific problems. At some UK universities, to simply affirm the existence of African intellectual production against longstanding historical silences, to affirm that the rest of the world has writing and thinkers that should be studied in any curriculum that claims general or global relevance - this can still be a radical idea when students can complete entire classes without reading non-white scholars. Elite UK universities can sometimes feel parochial and distant from global debates, movements and concerns, even as they claim privileged access to authoritative knowledge about, and the responsibility to solve problems for, the rest of the world. This article needs to be placed in this 
context so that it avoids being seen to re-inflate the importance of what happens at Western universities through the very process of seeking to question that importance. Failing to recognize decades of African and Pan-African struggles to decolonize curricula, universities and African Studies would only again pretend the universal significance of one provincial history of knowledge.

A critical decolonization of the university in the former metropole would thus leave the concept of decolonization open to contestation and seek conversation with its many histories. And so I will dig where we stand: in the Cambridge Centre of African Studies, of which I am the current director. Decolonization involves the excavation of the colonial origins, and the tracing of the colonial legacies, of our bodies of knowledge. It particularly requires attention to the institutions that produce and reproduce this knowledge, that enforce, sometimes violently, certain ways of knowing and producing knowledge as authoritative. Then we can address those institutional legacies explicitly. This can help illuminate the unspoken, perhaps unnoticed, limitations and conditions on what we know and how we learn, while also revealing other possibilities that may already exist within what we have.

\section{African Studies in the UK}

The African Studies Centre has been a key component of the institutional apparatus of British knowledge production on Africa since the 1960s, when such interdisciplinary centres were founded at many UK universities, including Cambridge (Richards 1967). The centres allowed an unprecedented professionalization of African Studies, which was consolidated with the creation of the African Studies Association-UK (ASA-UK) (Kirk-Greene 2000).

Before the African Studies centres, British knowledge production on Africa had taken different forms, including a history of racialized and racist knowledge on Africa (Amin 2010; Mbembe 2017; Mudimbe 1988; Lindqvist 1992). After the turn of the century, the Royal African Society assembled colonial officials, missionaries, medics and travellers interested in Africa, as did the International African Institute (Kirk-Greene 2000; McCracken 2007). Smuts' call in 1929 to transform Rhodes House at Oxford into a Centre of African Studies to study 'the African himself' failed to provide the impetus for new research he had hoped, so Hailey's African Survey of 1938, concluding with a chapter on 'The Future of African Studies', is often considered to have done the most to establish the field. Much early teaching on Africa was for colonial officers 
(Killingray 2000): in 1926, for instance, Cambridge organized, on the prompting of the Colonial Office, a postgraduate training course for Tropical African Service cadets and later created an African Summer School (Kirk-Greene 2000). Among academic disciplines, social anthropology had a particularly important role in the production of knowledge on Africa, as promoted by Hailey. Indirect Rule provided one key impetus: as anthropologist Godfrey Wilson explained in 1940, “Indirect Rule” demands respect for and deliberate utilization of African institutions. And no one can use to the best effect a material whose properties he only half understands' (Wilson 1940: 47).

World War II brought a reassessment of Britain's intellectual engagement with Africa, as the Scarborough Report of 1947 recommended more support to Area Studies with 'a policyinitiated emphasis on the cultural, political and economic future of the United Kingdom' (KirkGreene 2000: 25; Fage 1989). But aside from funding for language studies, little was done until the end of British colonialism in Africa was imminent. Then, the Hayter Report fundamentally transformed African Studies with its proposal to create a series of African Studies centres at British universities, lauding the US Area Studies centres and 'the stimulus a centre can give, and the way it can break down the barriers between disciplines' (quoted in Fage 1989: 407).

Birmingham was the first to move forward with its Centre of West African Studies. The plan involved a small, interdisciplinary academic staff, research fellows and research students, and a library; its Centre of West African Studies soon had over a dozen academic staff and forty postgraduate students (Fage 1989). The University Grants Committee provided funding for additional centres at Edinburgh and York, then Aberdeen, Sussex, Leeds and Cambridge. They were explicitly interdisciplinary - Edinburgh brought together an historian, a geographer, an anthropologist and a political scientist (Nugent 2009). These post-imperial centres were often staffed by returning British academics from the university colleges in Africa. Indeed, so important was this post-independence influx of academics that Fage (1989) cites the prior absence of these 'Africanists' from the UK as a key reason why African Studies took so long to consolidate. The centres thus represented what Kirk-Greene called the coming of age of the British Africanist community.

\section{The African Studies Centre: between the Cold War and colonialism}


Why was the interdisciplinary centre chosen as the privileged institutional form for knowledge production on Africa in the UK? The common answer, mentioned by the Hayter Report, is that Britain looked to US Area Studies centres for guidance in engaging intellectually with the Cold War, post-colonial world. The US African Studies centres have their own history, entwined with American racial and imperial politics (Martin and West 1999; Robinson 2007). Their origins lay in a 1948 Social Science Research Council report, which championed interdisciplinary Area Studies as part of the global Cold War. Area Studies was boosted by foundations, with more funding later provided under the 1958 National Defense and Education Act. The establishment of the US African Studies centres not only drew African Studies into the Cold War but also marginalized the existing tradition of African Studies based in historically black colleges and universities. Black scholars were excluded due to, in the words of Pearl Robinson, 'the prevailing view of influential scholars such as Herskovits, as well as decision-makers at key funding agencies, [which] held that African Americans could not be relied upon to produce scientifically objective research on Africa' (2007: 249; see also Pierre 2012: ch. 7).

There were certainly important parallels between the US African Studies centres and the British centres. Both were interdisciplinary, focused on the continent of Africa, largely disconnected from the study of the African diasporas, and had little room for African or black scholars. Both were supported by the state towards the end of serving the interests of world powers without formal colonial empires. However, to trace the entire institutional and epistemological inheritance of the UK centres to the US is inadequate. To do so is to ignore a specifically colonial origin of British African Studies centres and thus to fail to illuminate particular ways in which colonial legacies may still be present today.

To trace the origin of the British centres exclusively to the US is also historically inaccurate. The first interdisciplinary research institute for the study of Africa existed at least a decade before the first US African Area Studies centres and twenty-five years before those in the UK. It was established in colonial Africa: the Rhodes-Livingstone Institute (RLI), in what is today Zambia, set up by the colonial government there in 1938. Then, ten years later, the East African Institute of Social Research (EAISR, later renamed the Makerere Institute of Social Research, or MISR) was established at Makerere College in Kampala, along with the West African Institute of Social and Economic Research in Nigeria. The RLI was an independent initiative when it was founded, but by the end of World War II it and the other institutes had 
been incorporated into an overall plan for a 'developmental' empire (Cooper 2002) once the Colonial Development and Welfare Act had set the stage for an expansion of socially relevant research (Mills 2006: 81).

In this article, I look to these colonial institutes of social research in Africa as precursors to the British centre of African Studies as an institutional form. Today's centres might thus be understood, at least in part, as originally colonial technologies of knowledge production - not as copies of a US model with its political and racial dimensions, but rather as imports of colonial models with specifically colonial political and racial dimensions. And so perhaps the UK African Studies centres can be seen as an instance of institutions or techniques being developed in the colonial context before being brought back to the metropole, sometimes brought back to the UK by the very people who had staffed the African centres. In the case of the Cambridge Centre of African Studies, the continuity of personnel is clear: the founding director of EAISR was also the founding director of the Cambridge centre: anthropologist Audrey Richards. ${ }^{1}$ In addition to establishing both EAISR and the Cambridge centre, Richards was instrumental in shaping colonial policy on funding social science research in the colonies as well as encouraging government support for African Studies centres in the UK (Mills 2002). Decolonizing African Studies in the UK today thus requires significant attention to these colonial research institutes. Exploring them can reveal aspects of the colonial structure of knowledge production on Africa that can frame questions for us to ask of our centres today.

Paying attention to the knowledge produced by the colonial institutes as well as to the institutional structures that produced that knowledge can help reveal the complexity of identifying and addressing colonial legacies within African Studies today. This is because the institutes in some ways occupied an ambiguous position within colonialism, being, according to James Ferguson, 'on the liberal fringe of white colonial society' (Ferguson 1999: 28).

Researchers at the institutes often presented themselves as progressive intellectually and socially, as moving beyond prior anthropologists' exclusive focus on the 'tribe', as helping to solve problems of modernizing Africa, and as rejecting the conservatism of settler colonial society. Many of the researchers saw themselves as on the side of Africans, representing their interests, and helping to develop African researchers and leaders. This has led some to defend the institutes against charges of complicity with colonialism (Schumaker 2001, responding to Magubane 1971). Here, instead, I draw on Ferguson's argument that the researchers' 'position was one that 
existed within white colonial society, not against it; it was a position that found its definition and its moral purpose in its opposition to the white conservative, the "ignorant" racist settler ... The institute was, in the end, part of the colonial establishment, not some sort of alternative to it' (1999: 32). This position, of being within the colonial structure while using its academic space to push against what were seen as colonialism's worst aspects, can illuminate the institutes' work and will also have particular resonance with the question of decolonizing our centres today, I believe.

\section{Africa as object of research and development}

The RLI was founded in 1938 under the direction of British anthropologist Godfrey Wilson after much effort by the governor of Northern Rhodesia and with the significant support of Hailey (Brown 1973; Wilson 1940). The institute was committed to practical research for 'public service', in Wilson's words, intended 'as a contribution to the scientific efforts now being made in various quarters to examine the effect upon native African society of the impact of European civilization, by the formation in Africa itself of a centre where the problem of establishing permanent and satisfactory relations between natives and non-natives - a problem of urgent importance where, as in Northern Rhodesia, mineral resources are being developed in the home of a primitive community - may form the subject of special study' (Wilson 1940: 43). A decade later, EAISR drew on the RLI as a model to chart a similar agenda, committed to study the 'peoples and problems of East Africa' by undertaking 'sociological, linguistic, economic, legal and psychological studies' for the sake of the 'extension of our knowledge of the cultures and languages of the peoples of East Africa and of their present day reactions to modern political, economic and educational policies’ ('East African Institute of Social Research’1951).

Thus, neither the RLI nor EAISR claimed to study so-called primitive societies as isolated and timeless communities, as earlier anthropology had been accused of doing. On this, Wilson was emphatic: 'even the social anthropologists themselves have only just ceased their mental flight from the complexities of contemporary change in Africa; for years they took refuge in the relative stability of the remembered past, delicately averting their eyes from the semiliterate, semi-trousered informants' (1940: 47-48). Rather, it was 'social change' under colonial rule and capitalist expansion that was their privileged object of study (Ferguson 1999). To address these specifically 'colonial problems', in particular those arising from urbanization and 
migrant labour, the institutes sought to do research that bridged the rural and the urban, the traditional and the modern (Richards 1944, 1967). Wilson tellingly declared his object of research to be 'semi-detribalised Africans' (1940: 57), as part of this broad developmental agenda.

The institutes did not consider 'detribalization' and social change to be problems in themselves, as they were considered to be by colonial administrations anxious that modern pressures would lead 'tribal structures' to break down and cast Africans adrift (Mamdani 1996). Colonial rulers' concerns ranged from drinking in towns, to a labour force that refused to work, youth in revolt, corruption and crime, and urban disease and disorder. In this view, detribalization was a pathology, as Africans were understood as inherently belonging in tribal structures and thus incapable of productive functioning in modern society (Mbembe 2017; Pierre 2012). This focus on tribal structures was based upon an implicit racial division and drew, in Mafeje's words, 'an invidious and highly suspect distinction between Africans and other peoples of the world' (1971: 261). For the institutes' researchers, however, colonial problems were not caused so much by detribalization itself, but by colonial governments that failed to enact progressive policies for an Africa in transition and refused to treat urban, working Africans as modernizing subjects with the entitlements that implied.

The institutes thus produced research addressing what they understood as the coexistence of and relation between the traditional and the modern. As Richards explained: 'I planned that the first work to be done by the EAISR in 1950 should be a series of studies of the major ethnic groups in the area around Makerere and histories of some of the major industries' (1967: 50). Wilson laid out a precise time schedule of two years to study a specific problem in 'each small area', whether a 'tribe or a town' (1940: 59-60). Some emphasized one side of the dichotomy over the other: Gluckman's famous 1940 piece took colonial society as a whole as its object, whose primary structure was identified as race, a focus informed by his and other South African researchers' interest in using Northern Rhodesia as a laboratory for South Africa. But while some aspects of the institutes' work were expansive, encompassing even global economic forces, other aspects appeared to continue within a tribal model of research; Mafeje (1971) declared tribalism to be the institutes' ideology (see also Crehan 1997), and a report on EAISR's first conference included a list of researchers, each associated with a different tribe (Mbalibulha 2013). Or, as Richards wrote to Monica Wilson, 'Fallers arrives at the end of October to start on 
the Soga. Taylor is going to do the Zinza in the Biharamulo area. A Chicago lady, Priscilla Copeland is to do the Bahaya. A Dutchman is just coming to do the Ha. ... Middleton rather unhappy among the Lugbara’ (ibid.: 134).

'Peoples and problems', 'major ethnic groups' and 'major industries', a 'tribe or a town' - this dual object of research bore with it methodological implications, as interdisciplinarity was seen as necessary for understanding colonial problems. The methods of anthropology, developed around the study of the tribe, remained central, while the tools of modern social science were adopted alongside. This was visible in the personnel: EAISR was formed with an anthropologist as director and a staff of five other anthropologists, two urban sociologists, a linguist, an economist, a psychologist and a legal expert ('East African Institute of Social Research' 1951: 153). The interpenetration of rural and urban required the tools of each to be used on the other, and so rural research methods, in particular participant observation, were brought into urban areas, and urban research methods, some adopted from Chicago School sociology, were brought to rural areas (Schumaker 2001: 29). Anthropology was in some ways the master discipline, however, since it was required to adapt modern methods to Africa and develop 'research methods under East African conditions' ('East African Institute of Social Research' 1951: 152; Mills 2006). The institutes were thus seen as an opportunity for methodological development: EAISR undertook the 'organization of experiments in research methods', such as 'experiments in the techniques of urban social surveys under special African conditions', or 'studies of the success of the application of various psychological tests in different cultural back-grounds' ('East African Institute’ 1951: 152).

The institutes were engaged in problem-solving for development, even when it involved criticism of colonial policy. In their stated programmes, the institutes declared their commitment to 'cooperate as closely as possible with government research departments' ('East African Institute of Social Research' 1951: 152), and the institutes were dependent on the support of the colonial governments for their survival, governments that often looked at the institutes with suspicion (Brown 1973 Schumaker 2001). The institutes thus faced a 'fundamental ambiguity' in their endeavour to pursue independent research according to their own imperatives and interests and to publish sometimes uncomfortable findings (Brown 1973: 174), while also cultivating favour with colonial authorities (Mills 2006). It was an ambiguity that was at times resolved against researchers, for instance when Wilson was dismissed from the directorship of the RLI in 
1941. But the fact that this was a tension or ambiguity, rather than an outright conflict, speaks again to the fact that the institutes worked within, rather than against, the overall colonial structure. They were challenging what they saw as regressive aspects of colonial policy to different degrees, not colonial rule itself (Ferguson 1999). In Richards' case, Mills declares her to have been 'either politically naïve, or simply uninterested in the grievances of many Ugandans and Kenyans about the harsh inequalities of colonial rule' (2006: 90).

Valentin Mudimbe writes that, 'Because of the colonizing structure, a dichotomizing system has emerged, and with it a great number of current paradigmatic oppositions have developed: traditional versus modern; oral versus written and printed; agrarian and customary communities versus urban and industrialized civilization; subsistence economies versus highly productive economies. In Africa a great deal of attention is generally given to the evolution implied and promised by the passage from the former paradigms to the latter' (1988: 4). And so, even if the latter of each pair was privileged by the research institutes, the former remained crucial to the overall organizing dichotomy (Ferguson 1999). The institutes were implanted within the colonial structure in a particular way and looked to the colonial state as the agency for progressive social transformation, whose officials the institutes entreated to take guidance from their research.

\section{Researchers, assistants and race}

These progressive developmentalist researchers, with their innovative techniques, took Africans as their object of study. The institutes have been lauded for their long-term involvement with African communities and their commitment to building trust and relationships across racial lines (Schumaker 2001). But this did not change the fact that research was organized and carried out by whites on Africans. In broadest terms, research was extractive. Unpaid labour by Africans, in answering surveys, talking to interviewers and providing observations for participant observants, produced data that were processed by colonial researchers to develop theories and publications that they claimed as their own and used to advance their careers. Even if the research was done in the name of solving colonial problems for the benefit of Africans, and even if African research subjects were able to at times take advantage of researchers for their own ends, a basic racialized and colonial structure to the research pertained. The researchers' methods thus could appear similar to those of colonial administrators, who also had a history of collecting data in the name 
of benefiting Africans, and so it should not be a surprise that the researchers were often met with deep suspicion. It was, in Mafeje's words, sometimes 'impossible for the Africans to distinguish between' colonial administrators and researchers, 'politically and ideologically' (1997: 5).

In order to convince their research subjects that they were not government agents, the researchers depended upon the intermediary work of African research assistants. These assistants carried out surveys and interviews, translated, took field notes, helped with travel and logistics, and went places where white researchers would have had trouble (Kuper 1999). Lyn Schumaker cautions against condemning this arrangement as purely colonial and exploitative, directing attention to the agency of research assistants and to what she calls the 'co-production' of knowledge among assistants and researchers. She argues that assistants often considered themselves students more than exploited colonial subjects, used their knowledge in subsequent careers, and even at times exploited the anthropologists. The RLI is presented as 'an experiment in black/white relations' (Schumaker 2001: 247) and she goes so far as to argue that 'it is not only ethnographers, but anthropology itself that has been captured by Africans' (259). But the firm limits to this 'capture' were clear, as the institutes abided by the racialized lines of other colonial institutions. At the RLI, the researchers were all white, mostly British, South African or American. This was reflected in the institute's physical organization, with African quarters behind the main building (ibid.: 224). It was not until J. Clyde Mitchell's directorship that research assistants succeeded in changing their title from 'African Research Assistant' to 'Research Assistant' (ibid.). At EAISR, there were two Ugandan researchers in the 1950s, but all the other researchers were white.

The researcher-assistant relationship was also inflected by the idea of development. The institutes' directors declared their intention to train and eventually bring on African researchers. As the statement announcing EAISR's inception declared in 1950, at the end of a paragraph about training for Western researchers, 'it also hopes to train African investigators' ('East African Institute of Social Research' 1951: 152). At the RLI, Elizabeth Colson's 1948 research plan foresaw African senior research assistants - who had university education - being able to attend conferences and publish papers, although it is unclear to what degree this occurred (Schumaker 2001: 206). As to another director, Mitchell, Schumaker relates that, 'Although he didn't find Africans to fill the higher posts, Mitchell encouraged some of the assistants to continue their schooling and publish their research' - but again, whether this happened is not 
clear (ibid.: 224). ${ }^{2}$ Richards projected EAISR as helping to develop Social Studies teaching at Makerere, as having the responsibility to build a body of authoritative academic work on Africa that could be taught there (Mills 2006). She saw this British-led development of African intellectuals as being in the service of not only academic progress, but also gradual political progress: in a 1951 talk to Chatham House, she expressed her interest in EAISR and Makerere College eventually working together around teaching African development and hosting a 'discussion of alternatives, political alternatives, with educated Africans, with a great deal of discussion of the marked differences between British ideas and African ideas in different areas', which would be 'a useful intermediary process and would give the people in Uganda at any rate some kind of feeling of control'. ${ }^{3}$ This development and guidance of elites she cast as an intermediate stage on the way to self-rule.

Despite these frequent declarations of intent, however, Mwenda Ntarangwi et al. (2006: 22) conclude that the institutes were simply not successful in their 'original purpose' to 'build research capacity and train local researchers'. Richards herself in 1977 looked back and admitted that 'we should have made more determined efforts to speed up the training of nationals of the countries for which Great Britain was then responsible so that they could have started their own social research much sooner' (Mills 2006: 96). But even if they had succeeded in that objective, the underlying structure remained one of colonial institutions 'developing' Africans, modernizing individual researchers and intellectuals.

Schumaker downplays the failure of the research institutes to allow African research assistants to become researchers (despite their hopes to do so, which she documents), and focuses instead on how African research assistants in fact shaped, interpreted, produced and sometimes invented the knowledge that the researchers obtained. She asserts that anthropology was thus co-produced and Africanized. What this fails to address is how Africans' contribution was systematically not recognized by the institutes' researchers and was largely erased from academic production. Authoritative knowledge was claimed as the property of colonial researchers, regardless of how much labour Africans contributed. Furthermore, the power to define the topics of study and decide the purposes of research was in the hands of colonial academics. Africans could collect data and contribute to discussions around tools and methods, but analysis and theory was the preserve of whites, the most definitive of which increasingly took place in British universities. Recognition of the co-production of knowledge is important 
not in absolving the institutes of their colonial structure, but rather in showing how that structure erased that co-production of authoritative knowledge in favour of those with racialized authority.

What was not countenanced was that authoritative knowledge on Africa could be produced by Africans outside of the social science institutes. African knowledge was ignored except insofar as it conformed to and was intelligible within the parameters defined by colonial and metropolitan disciplinary knowledge. Again, the institutes saw themselves as creating knowledge about Africa upon a blank slate; when EAISR was established, Makerere's principal explained that there was no social science teaching at Makerere because 'teaching at a university level in the field of social studies will be impossible until local research can provide material for it' (Mills 2006: 84) - local research conducted by foreign researchers, which was EASIR's role.

In 1956, Audrey Richards returned to Cambridge, where she would eventually establish the African Studies Centre and become its first director. She also remained active in shaping British policy on research in Africa. She was particularly concerned, according to Mills, about falling standards of research in independent Africa: she feared that 'half-baked American students and quarter-baked African politicians' would direct academic inquiry and that governments might try to censor inconvenient findings (quoted in Mills 2006: 94). One idea she

had to combat this was to create a 'new organization to promote social science research' in Africa, effectively seeking to extend the 'intermediate stage' of British guardianship for intellectual development in Africa. By the late 1960s, with the founding of the Cambridge African Studies Centre and the ASA-UK, she remained concerned by 'the emphasis on shortterm practical objectives given by governments of the independent territories, who tend to be impatient of long-term research ... like their British counterparts in colonial days' (Richards 1967: 51). Her vision was for the ASA-UK to 'continue to press for the continuance of fundamental academic research in Africa as well as the purely practical', and she continued trying to organize research on an interdisciplinary, international basis towards the end of the development of research in Africa (ibid.).

\section{From colonial institute to British centre: Africa and the curriculum}

The colonial research institutes' experience gives rise to a series of questions that we can ask of African Studies centres today as part of a decolonization agenda. A first question concerns how Africa is constructed as an object of knowledge and to what extent colonial images of the 
continent remain embedded within African Studies today. Clearly, some of the most racist images of Africa, as a place of savagery and victimhood in need of a Western saviour, are still found in many mainstream representations of the continent (Harrison 2013; Mutua 2001). Centres of African Studies, therefore, can play an important role in decolonizing the image of Africa by denouncing these representations wherever they occur. But Africa was represented not only in overtly racist terms within colonial knowledge production. As recounted, many researchers at the institutes considered themselves anti-racist and critical of colonial racism; instead, it was a developmentalist paradigm that underpinned their image of Africa. Of course, it is not hard to find this externally-driven progressivist, developmentalist framework in much academic and policy knowledge produced about Africa today.

The institutes also raise the question of how race and tribe - or, in today's academic literature, ethnicity - define Africa as an object of study. A tension ran through the institutes' work between a tendency to foreground colonial societies, race, and regional and international structures, and a tendency to privilege the tribe as a unit of analysis even as it was transforming under modern conditions. Some scholars argue that African Studies today tends too much towards the latter. Jemimah Pierre (2012) makes the case that African Studies exhibits a systematic blindness to race and the continued role of racism, in particular global anti-black racism, in structuring post-colonial African politics and society. She identifies a continued tendency to draw the boundaries of African Studies at the borders of the continent, then to further define the proper object of study as areas racially identified as black - 'Sub-Saharan Africa' - and then to represent that African population as a vast constellation of different ethnicities, thus obscuring the role of race epistemologically and politically. Wale Adebanwi, the director of the African Studies Centre at Oxford, has argued that African Studies in the UK is generally restricted to the continent's boundaries and to an unstated focus on the difference of black African populations, with little attention to the dynamics of race on the continent (Public Lecture, Cambridge, 16 October 2017). Adebanwi has announced the Oxford Centre's reorientation towards 'Global Africa', which I understand to mean de-racializing the understanding of Africa as a continent - rejecting the unspoken limitation of the 'Africa' suitable for study to those populations and areas defined as black - while also foregrounding the continent's imbrication with regional and global systems and histories, including histories of race (Adomako Ampofo 2016). An audit of the papers presented in bi-annual ASA-UK conventions would be an 
important way of determining the current scope of British African Studies; for instance, the word 'diaspora' appears in the titles of only three of the more than six hundred panels at a recent convention; the word 'race' appears in the titles of six papers; and except for one panel on the Maghreb and two papers, North Africa is absent. ${ }^{4}$ Fortunately, there are vast intellectual resources close at hand that can be engaged to bring global dynamics and the question of race into conversation with British African Studies, found, among other places, in British scholarship on the Caribbean, the Black Atlantic (and Pacific), race in Britain and Black internationalisms.

A second question is whether Africa continues to be constructed as an object of knowledge by white researchers, and not as a place where knowledge is produced. Today's institutions of British African Studies can sometimes appear almost as racialized as they did in the colonial institutes. At Cambridge, there are no black members of our centre's Management Committee nor any permanent black academic staff teaching African Studies. Like the colonial institutes, the centre is predominantly comprised of white British, European, South African and North American staff, like myself. As to students, until this year, our MPhil students have also been mostly white. Throughout the UK, seminars and conferences often comprise majority white scholars speaking to majority white audiences; as a step towards changing this, we are proposing a commitment that all panels and conferences in which we are involved should comprise at least one-half scholars of colour, with preference given to African scholars and scholars based in African universities. If these conditions cannot be met, then perhaps the panel, series or conference simply should not happen - maybe it is better to have no conference at all than to have yet another conference of white scholars talking about Africa.

The curriculum is also a crucial place to investigate how Africa is situated relative to authoritative knowledge about Africa. Decolonizing the curriculum would require starting by deracializing the sources of the knowledge we teach. This does not mean just adding African authors to topics that have already been defined by British African Studies. This approach plucks scholars out of their contexts and reads them only for their relevance to current Western agendas. It fails to pay attention to African scholars' own intellectual contexts, traditions, and debates and discussions they are part of. The 'adding African authors' approach allows the major debates and paradigms to continue to be defined by the traditional Western arbiters of authoritative knowledge on Africa, with non-Western authors included who either speak to those debates or can be (mis)represented as doing so; Frantz Fanon's Wretched of the Earth is one text often 
appropriated in this way and thus divorced from African and transcontinental debates around decolonization, internationalism, race, class, psychology, philosophy, as well as violence and non-violence in political struggle. We cannot retain 'Conflict in Africa', 'Neopatrimonialism', 'Development', or 'Ethnicity' as the key subjects organizing our curriculum; instead, decolonizing would mean starting with attention to and learning from the specific, concrete debates that have taken place in specific locations in Africa and global Africa. A sustained engagement with these traditions can set the foundation for the work of new theorization and generalization.

The transformation of curricula in African Studies, however, is not enough, for it risks continuing to segregate knowledge from and on Africa. African Studies is not the only place where knowledge production about Africa takes place in the university, even if it takes place elsewhere through its disparagement or its absence from curricula, whether in political thought or French literature. For African Studies to be decolonized would thus also encompass a call to the rest of the university. African Studies centres can play a key role in this, being sites from where invitations and provocations are made, from where questions are asked that unsettle other disciplines. African Studies can show what a curriculum that starts from non-Western debates, thinkers, writers, institutions and traditions looks like; it can be a site from where non-hegemonic knowledge works its way out into the university as a whole (Mamdani 2016). This requires insisting on the fact that African political thought is political thought, in addition to being African Studies; African economic history is economic history and African literature is literature in addition to being African Studies. As Elísio Macamo puts it, 'Africa is what it is because of what the world is like, and vice versa. So we study Africa to understand the world' (2018: 8). And just as the African contribution to anthropology was systematically erased by a racist structure of authoritative knowledge production, so should other domains of what is claimed as Western knowledge be interrogated for African contributions.

\section{The practice of research on Africa: collaboration}

Today's practice of research also requires interrogation. Extractivist, unaccountable research is still being carried out in Africa across the disciplines as well as by policy organizations and aid agencies. These are practices that Centres of African Studies have a responsibility to expose and denounce. The research assistant culture is also still alive and well today in much research in 
Africa, perhaps even more so with the dominance of short-term research trips and consultancies. The questions raised about research assistants at the colonial institutes need to be raised for today's relationships as well. Exploitation remains a crucial issue, as does the difficulty, often impossibility, for research assistants to achieve a professional academic career despite being deeply involved in the production of academic knowledge for a longer time than most PhD holders. The contributions of African research assistants to authoritative knowledge remain obscured or ignored, their names relegated to the acknowledgements.

Today, more formal collaboration is on the British agenda with a push by funding agencies and UK universities for research on Africa to proceed in collaboration with African researchers and institutions. All this is in the name of 'genuine' partnership and co-production of knowledge, of going beyond exploitative and extractivist Western research in Africa. As with the colonial research institutes, today's partnerships are also typically presented as being beneficial to Africa in the name of 'capacity building' and 'developing' African researchers and institutions. Centres of African Studies often find themselves in the middle of this dynamic, asked to facilitate partnerships and help organize, host and guide collaborations. Here, too, a series of questions arise. For one thing, the scramble for individual African 'partners' may be undermining the very universities that such partnerships claim to be supporting. More fundamentally, we need to ask to what degree these research collaborations, even when they are with established academics in African universities, remain defined by racialized, colonial structures of knowledge production. Just as Africans were research assistants, data collectors and translators in the colonial institutes, to what degree do today's African 'partners' remain largely assigned to the empirical side of research by collaborations, while analysis and theorization is considered to occur in the West, the preserve of mostly white researchers?

Steps can be taken to address some of these problems of extractivist and collaborative research. Western researchers should start by attending to and joining, if invited, academic debates and agendas happening in African universities and research institutes. Research 'collaborations' should involve a non-negotiable commitment to provide the same access to academic literature to all the partners, so that Western-based researchers cannot claim a monopoly on access to authoritative knowledge. Any texts produced should join a global commons, equally accessible in African or Western universities. And all research produced on Africa should be primarily presented in African forums, thus making Western-based research 
and researchers at least somewhat accountable to those they are writing about. Engagement with continental research organizations, such as CODESRIA or the African Studies Association of Africa, can be an important step in this direction.

Colonial interdisciplinarity was problem-solving interdisciplinarity for development, as various tools were required to grasp different sides of colonial problems. This kind of problemsolving interdisciplinarity can, of course, still be found today. The massive funding available under the Global Challenges Research Fund entails a significant emphasis on interdisciplinary work; however, this interdisciplinarity is still largely in problem-solving, or challenge-solving, mode, equated with development. The neoliberal university sees Africa as a realm of problems and thus a good way for attracting large problem-solving research grants to the university, which claims to have the knowledge to solve those African problems. Just as the institutes saw Africa as a field for experimentation with novel research techniques, so too does Africa today remain a place of testing and developing research methods, which can often be done without accountability.

However, this is not the only form of interdisciplinarity that centres can enable (Mamdani 2016; Zeleza 2007). Critical interdisciplinarity is also possible, the point of which is precisely to question the assumptions underlying one discipline from the perspective of another. This helps open the way for forms of non-hegemonic knowledge, and even for undisciplinary or antidisciplinary knowledge. As Macamo writes, 'We study Africa because we want to know how to study Africa ... Scholarship ... [is] defined by the ability to reflect on the best way to organize our ways of knowing' (2018: 8). This kind of critical interdisciplinarity in the field of African Studies is being explored provocatively, for instance, in the science and technology agenda being developed by Clapperton Chakanetsa Mavhunga (2017). Centres can make possible this critical interdisciplinarity and a sustained engagement with systems of knowledge outside those dominant in British universities.

Such reforms are important, but decolonization would require transforming the structure of collaborative knowledge production itself. The colonial structure that gave rise to British African Studies and that underlies today's collaborations first needs to be recognized, and then new arrangements can be built upon that recognition by critically engaging with, not ignoring, the colonial histories and legacies of knowledge production about Africa. The research institutes were nodes in a transnational, largely colonial, matrix of institutions and circulations of scholars 
among the UK (especially Oxford, the London School of Economics, Cambridge and Manchester), university colleges in African colonies, South African universities (in particular Wits and University of Cape Town) and universities and foundations in the US, which contributed Fulbright researchers, funding and research tools (Schumaker 2001: ch. 2). This was a racialized transnationalism, since it was a circulation of almost exclusively white scholars through these institutions, all of which played important intellectual and political functions in the intensely racialized societies in which they were situated. It is through these common histories that Africa as the object of study was formed; it is in engaging those common histories and seeking collectively to go beyond them that African Studies can be rethought and decolonized.

New forms of collaboration around research and teaching, around the production of knowledge and the definition of authoritative knowledge, can be mapped onto these common histories. Research can, for instance, focus on the intellectual work of African researchers and research assistants, those who were targeted for development both during and after colonialism. Indeed, research assistants were often part of transnational circulations of their own, as Schumaker relates, among different universities, institutes and various intellectual and political roles throughout Southern Africa. Lungisile Ntsebeza's ongoing work on Archie Mafeje exemplifies this method for decolonizing African Studies. Mafeje began his academic career at UCT, where he worked with Monica Wilson, who, together with her husband Godfrey Wilson, had been part of the first generation of researchers at the RLI. He went to Cambridge on Wilson's recommendation, where he completed his $\mathrm{PhD}$ under Audrey Richards' supervision. He spent time at EAISR in the 1960s conducting research, before being refused a lectureship at UCT in 1968, to go on to an unwavering critique of Africanist anthropology (Ntsebeza 2016). Mafeje's is a counter-history of African Studies, one that maps geographically and institutionally onto the dominant networks that produced African Studies, contesting their colonial dimensions at every step. Ntsebeza, currently director of the Centre of African Studies at UCT, presented his research on Mafeje at the Cambridge Centre of African Studies' 2018 Audrey Richards Distinguished Lecture, sparking a wave of interest and debate. Collective explorations of shared colonial legacies by the very institutions that had been involved in the production of those legacies can thus produce counter-histories of African Studies towards decolonization.

This effort can also involve recuperative research agendas within UK universities: for instance, at Cambridge, the Black Cantabs Society is doing critical work as a student 
organization writing histories of black students at Cambridge. But the work of decolonization cannot become yet more unpaid labour by students, especially students of colour. Structures need to be established in which staff work alongside students, and students are paid or get course credit for decolonizing work. It is only by building a community of students and staff around African Studies that the debates will occur that can push forward the process of decolonization, providing the collective strength to engage with universities for whom questions of race and decolonization have not been a priority.

\section{After the British African Studies Centre}

What should the future be of the discourses and institutions gathered around British African Studies, if decolonization is the goal? One dilemma is that the very category 'Africa' may be so bound up with its colonial construction that African Studies may not even be conceivable outside

of colonial structures of knowledge. But equally, we might ask whether British African Studies is conceivable outside of colonial, racialized structures of knowledge, given the importance of those structures, even implicitly, to the image of Britain within British academia. So, for British African Studies to be decolonized might require transformations in the idea of Africa and in the idea of Britain so fundamental that neither would be recognizable within its current parameters. But even if a decolonized British African Studies is an impossibility, a British African Studies in the process of decolonization is crucial. A decolonizing British African Studies can be a site from where colonial and racial legacies are continually foregrounded, categories of knowledge critiqued, the bounds to authoritative knowledge questioned, and demands for justice made. In our current context of Brexit, the importance of a decolonizing British African Studies is growing, and Centres of African Studies can have a key role to play, most urgently and practically as sites of anti-racism, starting in our own universities. 


\section{References}

Adi, H. 1998. West Africans in Britain 1900-1960: Nationalism, Pan-Africanism and Communism. London: Lawrence and Wishart.

Adomako Ampofo, A. 2016. 'Re-viewing Studies on Africa, \#Black Lives Matter, and Envisioning the Future of African Studies'. African Studies Review 59 (2): 7-29.

Amin, S. 2010. Eurocentrism. New York: Monthly Review Press.

Brown, R. 1973. 'Anthropology and Colonial Rule: Godfrey Wilson and the Rhodes-Livingstone Institute'. In T. Asad (ed.), Anthropology and the Colonial Encounter. New York: Humanities Press, 173-198.

Bundy, C. 2002. 'Continuing a Conversation: Prospects for African Studies in the 21st Century'. African Affairs 101: 61-73.

Cooper, F. 2002. Africa since 1940: The Past of the Present. Cambridge: Cambridge University Press.

Crehan, K. 1997. The Fractured Community: Landscapes of Power and Gender in Rural Zambia. Berkeley, CA: University of California Press.

'East African Institute of Social Research'. 1951. Sudan Notes and Records 32 (1): 151-153.

Fage, J. D. 1989. 'British African Studies since the Second World War: A Personal Account'. African Affairs 88 (352): 397-413.

Fanon, F. 1965. Wretched of the Earth. New York: Grove Press.

Ferguson, J. 1999. Expectations of Modernity: Myths and Meanings of Urban Life on the Zambian Copperbelt. Berkeley, CA: University of California Press.

Gilroy, P. 1993. The Black Atlantic: Modernity and Double Consciousness. Cambridge, MA: Harvard University Press.

Gluckman, M. 1940. 'Analysis of a social situation in modern Zululand'. Bantu Studies 14 (1): 1-30.

Hailey, W.M. 1938. An African Survey: A Study of Problems arising in Africa South of the Sahara. Oxford: Oxford University Press.

Hall, S. 2017. The Fateful Triangle: Race, Ethnicity, Nation. Cambridge, MA: Harvard University Press.

Harrison, G. 2013. The African Presence: Representations of Africa in the Construction of Britishness. Manchester: Manchester University Press. 
Killingray, D. 2000. 'Colonial Studies'. In D. Rimmer and A. Kirk-Greene (eds), The British Intellectual Engagement with Africa in the Twentieth Century. Basingstoke: Macmillan, $41-67$.

Kirk-Greene, A. 2000. 'The Emergence of an Africanist Community in the UK'. In D. Rimmer and A. Kirk-Greene (eds), The British Intellectual Engagement with Africa in the Twentieth Century. Basingstoke: Macmillan, 11-40.

Kuper, A. 1999. Among the Anthropologists. London: Athlone Press.

Lindqvist, S. 1992. Exterminate all the Brutes. New York: New Press.

Lonsdale, J. 2005. 'African Studies, Europe \& Africa'. Afrika Spectrum 40 (3): 377-402.

Macamo, E. 2018. 'Urbane Scholarship: Studying Africa, Understanding the World'. Africa 88 (1): $1-10$.

Mafeje, A. 1971. 'The Ideology of Tribalism'. Journal of Modern African Studies 9 (2): 253261.

Mafeje, A. 1997. 'Who Are the Makers and Objects of Anthropology? A Critical Comment on Sally Falk Moore's “Anthropology and Africa"'. African Sociological Review 1 (1): 115.

Magubane, B. 1971. 'A Critical Look at Indices Used in the Study of Social Change in Colonial Africa'. Current Anthropology 12 (4/5): 419-445.

Mama, A. 2007. 'Is it Ethical to Study Africa? Preliminary Thoughts on Scholarship and Freedom'. African Studies Review 50 (1): 1-26.

Mamdani, M. 1996. Citizen and Subject. Princeton, NJ: Princeton University Press.

Mamdani, M. 2016. 'Between the Public Intellectual and the Scholar: Decolonization and Some Post-Independence Initiatives in African Higher Education'. Inter-Asia Cultural Studies 17 (1): 68-83.

Martin, W. and M. West (eds). 1999. Out of One, Many Africas: Reconstructing the Study and Meaning of Africa. Urbana: University of Illinois Press.

Mavhunga, C. C. 2017. What Do Science, Technology, and Innovation Mean from Africa? Cambridge, MA: MIT Press.

Mbalibulha, S. B. B. 2013. 'The History of Makerere Institute of Social Research (MISR) and Her Place in the Study of the Social Sciences in Africa'. Journal of Higher Education in Africa (IHEA/RESA) 11 (1-2): 121-142. 
Mbembe, A. 2017. Critique of Black Reason. Durham, NC: Duke University Press.

McCracken, J. 2007. 'New Directions in African Studies in the United Kingdom'. In P. T. Zeleza (ed.), Study of Africa: Volume 2: Global and Transnational Engagements. Dakar: CODESRIA, 146-156.

Mills, D. 2002. 'British Anthropology at the End of Empire: the Rise and Fall of the Colonial Social Science Research Council, 1944-1962'. Revue d'Histoire des Sciences Humaines 6 (1): $161-88$.

Mills, D. 2006. 'How Not to Be a "Government House Pet": Audrey Richards and the East African Institute for Social Research'. In M. Ntarangwi, D. Mills and M. Babiker (eds), African Anthropologies: History, Critique and Practice. London/Dakar: Zed/CODESRIA, 76-98.

Mudimbe, V. Y. 1988. The Invention of Africa. Bloomington: Indiana University Press.

Mutua, M. 2001. 'Savages, Victims, and Saviors: The Metaphor of Human Rights'. Harvard International Law Journal 42 (1): 201-45.

Ntarangwi, M., D. Mills and M. Babiker. 2006. African Anthropologies: History, Critique and Practice. London/Dakar: Zed/CODESRIA.

Ntsebeza, L. 2016. 'What Can We Learn from Archie Mafeje about the Road to Democracy in South Africa?' Development and Change 47 (4): 918-936.

Nugent, P. 2009. 'Critical African Studies: A Voluntarist Manifesto'. Critical African Studies 1 (1): $1-19$.

Pierre, J. 2012. The Predicament of Blackness. Chicago: University of Chicago Press.

Richards, A. 1944. 'Practical Anthropology in the Lifetime of the International African Institute'. Africa 14 (6): 289-301.

Richards, A. 1967. 'Presidential Address'. African Affairs 66 (262): 40-54.

Robinson, P. T. 2007. 'Area Studies in Search of Africa: The Case of the United States'. In P. T. Zeleza (ed.), Study of Africa: Volume 2: Global and Transnational Engagements. Dakar: CODESRIA, 235-276.

Schumaker, L. 2001. Africanizing Anthropology: Fieldwork Networks and the Making of Cultural Knowledge in Central Africa. Durham, NC: Duke University Press.

Wilson, G. 1940. 'Anthropology as a Public Service'. Africa 13 (1): 43-61.

Zeleza, P. T. 1997. Manufacturing African Studies and Crises. Dakar: CODESRIA. 
Zeleza, P. T. (ed.). 2007. Study of Africa: Volume 2: Global and Transnational Engagements.

Dakar: CODESRIA.

\section{Notes}

1. EAISR had one director appointed before Richards, but he advised against the establishment of the institute (Mbalibulha 2013; Mills 2006). Before coming to Cambridge, I was senior research fellow at MISR for several years and so this article draws on that experience as well. 2. Schumaker reports that Mitchell published the best of the senior assistants' work at the institute and cited it in his own papers (2001: 211), but only apparently unpublished manuscripts contained within Mitchell's papers are cited in her bibliography (213n67).

3. MISR Archive, The Royal Institute of International Affairs, African Group Meeting, 18.1/4, 10 October 1951, 'Present Day Changes in Political Leadership in the East African Tribes'.

4. A similar trend is reported by Adomako Ampofo: in the US ASA's African Studies Review, ' 1.3 percent of articles directly addressed what I would consider the topics of Black lives, the African diaspora, or pan-Africanism’ (2016: 16). 